\title{
Growth of Stone pine (Pinus pinea L.) European provenances in central Chile
}

\author{
Verónica Loewe Muñoz ${ }^{(1)}$, Mónica \\ Balzarini ${ }^{(2)}$, Claudia Delard \\ Rodríguez ${ }^{(1)}$, Andrea Álvarez \\ Contreras ${ }^{(1)}$, Rafael María \\ Navarro-Cerrillo ${ }^{(3)}$
}

\begin{abstract}
Pinus pinea is characterized by phenotypic plasticity, tolerance to harsh soils and climates, but low differentiation in growth parameters and low genetic variability. Growth and cone production of six European stone pine provenances (two from Italy, three from Spain and one from Slovenia) were analyzed in a field trial experiment established in central Chile. The study evaluated height, diameter at breast height (DBH) and crown diameter growth of 147 nineteen-year-old trees per provenance, as well as fruiting variables (i.e., number of cones per tree and cone weight). Survival over the first 7 years was also evaluated. Provenances significantly differed in cone number per tree, cone weight, height and DBH growth, and crown diameter growth. Provenances were grouped according to growth and production variables: one group included the Italian and Slovenian provenances, the second group Andalucía and Sierra Morena (Spain), and the third included Meseta Castellana (Spain). Individual cone production was positively correlated with cone weight and other growth variables. Meseta Castellana provenance showed the highest growth and productivity. Our results provide useful information for the selection of $P$. pinea provenances to be used in new plantations in central Chile.
\end{abstract}

\section{Keywords: Cone Productivity, Growth, Provenances, Stone Pine Plantations}

the high densities they were planted ( 4400 to 10000 trees $\left.\mathrm{ha}^{-1}\right)$, and several isolated trees exist in the area with diameter at breast height (DBH) above $1 \mathrm{~m}$. Later, the species was included in other afforestation and rural development programs (Loewe \& Delard 2012).

Starting from 1990s, Stone pine was studied as a potential alternative forest crop for the Mediterranean zone of Chile. Suitable cultivation areas were assessed to cover as much as 1.3 million hectares up to $1000 \mathrm{~m}$ a.s.l. (Loewe \& González 2003), but Stone pine was later found to survive at above $2000 \mathrm{~m}$ a.s.l. Despite the sensitivity of the species to soil conditions (Gandullo \& Sánchez-Palomares 1994, Court-Picon et al. 2004, Mutke et al. 2007, 2013) it has been reported that Stone pine can grow over more than 8.6 million hectares, with over 4.8 million hectares being suitable for medium and high levels of pine nut produc-
(1) Chilean Forest Institute (INFOR), Santiago (Chile); (2) CONICET Biometry Unit, College of Agriculture, Universidad Nacional de Córdoba, Córdoba (Argentina); (3) DendroLab, Dpto. Ingeniería Forestal, ETSIAM Universidad de Córdoba, Córdoba (Spain)

@ Verónica Loewe Muñoz (vloewe@infor.cl)

Received: Jan 17, 2016 - Accepted: May 09, 2016

Citation: Loewe Muñoz V, Balzarini M, Delard Rodriguez C, Álvarez Contreras A, NavarroCerrillo RM (2016). Growth of Stone pine (Pinus pinea L.) European provenances in central Chile. iForest 10: 64-69. - doi: 10.3832/ifor1984-009 [online 2016-08-29]

Communicated by: Gianfranco Minotta tion (Ávila et al. 2012).

Pinus pinea is characterized by a high phenotypic plasticity and adaptability (e.g., it tolerates extreme soil and climatic conditions), but it shows a strong sensitivity to intra- or interspecific competition (Mutke et al. 2008). However, a limited genetic variability among provenances and their low differentiation in growth have been reported by numerous studies, thus hampering both conservation and breeding programs (Sánchez-Gómez et al. 2009). For example, Fallour et al. (1997) studied the isozyme variation in Stone pine populations from Spain, France, Greece, Italy, Lebanon, Portugal and Turkey, attributing the low variability detected to a decrease in population size during the Quaternary glacial period. Gómez et al. (2002) analyzed 10 Spanish populations and found lower values of the genetic variability as compared to other Mediterranean pines. Evaristo et al. (2002) using RAPD markers classified 22 provenances from Portugal, Spain, Italy, Greece, Morocco, Turkey and Israel into four close genetic groups, being the Italian and Portuguese provenances those showing the highest and lowest genetic diversity, respectively. Gordo et al. (2007) detected almost null differentiation between stands from the Meseta Norte (Spain) provenance. Vendramin et al. (2008) found very low genetic diversity in Pinus pinea using 12 paternally-inherited chloroplast microsatellites (see also Allal et al. 2011). Using both nuclear and organelle markers, González (2011) found very low molecular variation in the species, though 
sufficient to separate eastern (Greece, Turkey, Israel, Cyprus and Lebanon) from western provenances (Spain, France, Italy, Morocco and Tunisia). Mutke et al. (2005) studied height growth of Spanish, French, Lebanese, Turkish, Portuguese, Greek and Italian provenances in young trees established at three sites of Spain, and found sig nificant differences partly masked by the strong environmental heterogeneity within and between sites. Khaldi et al. (2009) found differences in survival and growth of different provenances established in two sites of Tunisia. Nasri et al. (2005) studied fatty acids of seeds in French and Turkish provenances, and the low genetic diversity detected was attributed to the homogeneity of the reproductive material due to the human-induced species propagation. Likewise, Evaristo et al. (2008) indicated a lack of differentiation between provenances in relation with growth.

Although Stone pine is a very attractive species in Chile due to its vigorous growth, good phytosanitary conditions and high pine nut production (Loewe \& González 2007), no studies have been carried out in Chile focusing on differences in cone production among provenances. The objective of this study was to compare the genetic variability of six Stone pine European provenances growing under harsh soil and climatic conditions in central Chile, in terms of growth and production, i.e., tree survival, height growth, DBH growth, crown diameter growth, number of cones per tree and cone weight.

\section{Materials and methods}

Vegetal material and experimental area This study examined six European provenances of Stone pine, three from the west and three from the middle of the Mediterranean Basin, covering a wide range of natural environments of this species in Southern Europe. The main characteristics of native areas for each tested provenance are presented in Tab. 1 (for more information, see Gandullo \& Sánchez-Palomares 1994, Prada et al. 1997). Of the three Spanish provenances, Meseta Castellana and Western Andalucia are among the most productive in that country, while the provenance Sierra Morena covers a wide area in Spain with fragmented and small natural populations (Calama 2004). In Italy, the species has been introduced long time ago, and is distributed mostly along Tyrrhenian coastal areas (Liguria, Tuscany, Lazio and Campania) and in Sicily and Sardinia (Peruzzi et al. 1998, Raimondo 2013). However, no studies describing Italian provenances have been reported.

The provenance trial is located in Casablanca, Valparaiso region (Chile) where the climate is typically Mediterranean with long dry summers and short rainy winters. Mean temperatures (since establishment up to 2013) showed seasonal differences, with $17.3^{\circ} \mathrm{C}$ in summer and $9.2{ }^{\circ} \mathrm{C}$ in winter; daily temperature fluctuations are wide, ranging from 8.2 to $27.4{ }^{\circ} \mathrm{C}$ in summer and from 3.3 to $17^{\circ} \mathrm{C}$ in winter. Annual rainfall is $285.8 \mathrm{~mm}$, of which only $0.6 \mathrm{~mm}$ falls in summer, being highly irregular among years. The dry season spans on average 8 months, varying between 5 and 10 months (Tab. 1).

The studied plots are located on gentle slopes where no agricultural or forest crops were present before the establishment of the stone pine plantation. The soil is composed by $68 \%$ sand, $23 \%$ lime and $9 \%$ clay, with neutral $\mathrm{pH}$ (6.6), low organic matter content (0.9\%), no salt $(\mathrm{EC}=0.33$ mmho $\left.\mathrm{cm}^{-1}\right)$, very low nitrogen $(<10 \mathrm{mg}$ $\left.\mathrm{Kg}^{-1}\right)$, potassium (53 $\left.\mathrm{mg} \mathrm{Kg}^{-1}\right)$, sulphur ( $<2$ $\left.\mathrm{mg} \mathrm{Kg}{ }^{-1}\right)$, zinc $\left(0.22 \mathrm{mg} \mathrm{Kg}^{-1}\right)$ and boron ( 0.2 $\mathrm{mg} \mathrm{Kg}{ }^{-1}$ ); low phosphorus content (9 $\mathrm{mg}$ $\left.\mathrm{Kg}^{-1}\right)$; and medium copper ( $\left.0.88 \mathrm{mg} \mathrm{Kg}^{-1}\right)$, manganese $\left(7.6 \mathrm{mg} \mathrm{Kg}^{-1}\right)$ and iron $(14.7 \mathrm{mg}$ $\left.\mathrm{Kg}^{-1}\right)$ content. This soil is very restrictive to vegetation growth due to the presence of a hard subsoil layer encrusted with calcium-carbonate at variable depths.

\section{Experimental design}

A randomized complete block design was established including three blocks, with each provenance being represented by 49 trees per plot and one row buffer planted around plots. We used a $2 \times 3 \mathrm{~m}$ setting for a total area of 0.7 ha. Blocks had different soil conditions regarding soil depth (I: 70 $\mathrm{cm}$ of which $20 \mathrm{~cm}$ occupied by roots; II: 78 $\mathrm{cm}$ of which $30 \mathrm{~cm}$ occupied by roots; III: $93 \mathrm{~cm}$ of which 70 occupied by roots). Soil was analyzed at several sampling points selected systematically following a zigzag pattern, with soil samples taken from three depth levels at each point.

In August 1994, 2-year-old P. pinea seedlings grown in $210 \mathrm{~cm}^{3}$ containers in coco fiber-peat-vermiculite (2:1:1) substrate were planted at the experimental site. Mean seedling height before transplanting was $44 \pm 7 \mathrm{~cm}$, and mean collar diameter was $0.9 \pm 0.12 \mathrm{~cm}$ (Loewe \& González 2003). The planting area was prepared via complete ploughing and ripping on the plantation line at $30-40 \mathrm{~cm}$ depth, and planting was performed manually following a systematic spatial pattern distribution $(2 \times 3 \mathrm{~m})$ with an initial density of 1667 trees ha-1. After plantation, irrigation ( 5 I plant ${ }^{-1}$ ) was applied, and arboriculture techniques were adopted in order to maximize cone production: weed control ( 1,3 and 4 years after planting), fertilization (urea $35 \mathrm{~g} \mathrm{plant}^{-1}$ at planting and 3, 4 and 5 years after planting); formation pruning (apical selection, balance pruning in inclined trees, and the elimination of the widest branches in some verticils, 5, 7, 11 and 15 years after planting; in the first pruning, all juvenile basal branches with no verticil structure were also cut); cleaning pruning ( 8 and 15 years after planting), and thinning (15 years after planting), when half of the trees were removed.

\section{Growth and cone production measurements}

A field inventory was conducted 19 years after plantation (in winter 2013), and DBH, total height $(H)$, and crown diameter (CD) were recorded for all trees in each plot and block. Diameters were measured to the nearest $0.1 \mathrm{~cm}$ with a graduated caliper in two perpendicular directions. Trees were marked with paint at $1.30 \mathrm{~m}$ above the ground to ensure that diameter measurements were taken at the same point. Tree height was measured to the nearest $0.1 \mathrm{~m}$ with a hypsometer. Crown diameter was defined as the distance between the crown projections of living branches. All cones from each tree were harvested and weighed individually using a precision scale. Cone yield ( $\left.\mathrm{kg} \mathrm{ha}^{-1}\right)$ was calculated based on cone number and weight. Survival was assessed by counting living trees on each measurement date during the first 7 years.

Tab. 1 - Characteristics of the native area for the tested provenances, provenance germination rate in Chile and trial site description. (IT): Italy; (SLO): Slovenia; (SP): Spain. Source: WorldClim Database (Hijmans et al. 2005); Casablanca data were taken from http://www.meteochile.gob.cl.

\begin{tabular}{|c|c|c|c|c|c|c|c|}
\hline \multirow{2}{*}{ Kind } & \multirow{2}{*}{ Site } & \multicolumn{2}{|c|}{ Location } & \multirow{2}{*}{$\begin{array}{l}\text { Altitude } \\
\text { (m a.s.l.) }\end{array}$} & \multirow{2}{*}{$\begin{array}{c}\text { Annual } \\
\text { Rainfall } \\
\text { (mm) }\end{array}$} & \multirow{2}{*}{$\begin{array}{c}\text { Annual Mean } \\
\text { Temperature } \\
\left({ }^{\circ} \mathrm{C}\right)\end{array}$} & \multirow{2}{*}{$\begin{array}{c}\text { Germination } \\
(\%)\end{array}$} \\
\hline & & Latitude & Longitude & & & & \\
\hline \multirow[t]{5}{*}{ Provenance } & 1 Lombardy (IT) & $45^{\circ} 07^{\prime} 00^{\prime \prime} \mathrm{N}$ & $09^{\circ} 05^{\prime} 00^{\prime \prime} \mathrm{E}$ & 123 & 1021 & 13.1 & 43.2 \\
\hline & 3 Slovenia (SLO) & $45^{\circ} 52^{\prime} 00^{\prime \prime} \mathrm{N}$ & $16^{\circ} 03^{\prime} 06^{\prime \prime} \mathrm{E}$ & 293 & 1263 & 9.0 & 51.6 \\
\hline & 4 Meseta Castell. (SP) & $41^{\circ} 10^{\prime} 60^{\prime \prime} \mathrm{N}$ & $04^{\circ} 17^{\prime} 60^{\prime \prime} \mathrm{W}$ & 845 & 423 & 11.9 & 72.8 \\
\hline & 5 West. Andalucia (SP) & $36^{\circ} 38^{\prime} 60^{\prime \prime} \mathrm{N}$ & $05^{\circ} 41^{\prime} 00^{\prime \prime} \mathrm{W}$ & 93 & 707 & 17.2 & 34.0 \\
\hline & 6 Sierra Morena (SP) & $37^{\circ} 51^{\prime} 00^{\prime \prime} \mathrm{N}$ & $06^{\circ} 16^{\prime} 60^{\prime \prime} \mathrm{W}$ & 337 & 585 & 16.7 & 71.6 \\
\hline Trial Site & Casablanca (Chile) & $33^{\circ} 22^{\prime} 38^{\prime \prime} \mathrm{S}$ & $71^{\circ} 19^{\prime} 19^{\prime \prime} \mathrm{W}$ & 330 & 286 & 14.4 & - \\
\hline
\end{tabular}




\section{Statistical analyses}

Kaplan-Meier survival curves and Log Rank Test $(\alpha=0.05)$ were used to compare stand survival among provenances. Height, diameter and cone production were examined to ensure that the variables were normally distributed.

ANOVA linear mixed models were used (West et al. 2014) to account for spatial correlation among trees. Fitted mixed models included provenances and blocks as fixed effects, and density as a covariate. A spatial exponential model was used for the model error terms; two structures for the residual (co)variance matrix were tested, including: (1) an exponential spatial model (EXP), and (2) a spatially uncorrelated model (Littell et al. 2006). Parameters were estimated by restricted maximum likelihood (REML). The best model was selected based on the Akaike's information criterion (AIC). A comparison of initial tree sizes among provenances revealed non-significant differences $(p<0.05)$. Finally, a multivariate analysis was performed using Cluster (average linkage method, Euclidean distance) and principal component analysis (PCA), generating a biplot of growth and productivity variables according to provenances and blocks. Statistical analyses were performed using SAS PROC MIXED version 9.3 (SAS Institute 2006).

\section{Results}

Plant mortality was on average 15\% during the first 7 years after plantation. The Log Rank Test applied to the estimated survival curves for provenances showed significant statistical differences $\left(\chi^{2}=35.9, p<0.0001\right)$. The proportion of $P$. pinea plants that survived 7 years after plantation was higher for the Spanish and Slovenian provenances ( $88 \%$ on average) than for the Italian provenances, which showed the lowest survival over the same period ( $81 \%$ on average Fig. 1).

According to the Akaike criterion, the spatial autocorrelation was no statistically significant. However, density effect was a significant covariable for tree cone production $(p=0.0017)$, cone weight $(p<0.0001)$, DBH $(p=0.0092)$ and crown diameter growth ( $p=0.007-$ Tab. 2$)$.

Average growth and cone production by provenances are presented in Tab. 3. At the studied age (19 years after planting), all of the variables showed significant differences among provenances $(p<0.05)$. The Italian provenances showed significantly lower height, $\mathrm{DBH}$ and crown diameter than the Spanish and Slovenian provenances. Average cone production of all provenances was 8.3 cones tree ${ }^{-1}$, with an average cone weight of $284 \mathrm{~g}$ and a mean cone yield of $1494 \mathrm{~kg} \mathrm{ha}^{-1}$. All of trees had cones, ranging between a minimum of 1 and a maximum of 22 cones. Meseta Castellana showed the highest values among all the provenances for DBH $(17.3 \mathrm{~cm})$, crown diameter $(3.6 \mathrm{~m})$, cone yield ( 1860 $\mathrm{kg} \mathrm{ha}^{-1}$ ) and cone number (11 cones tree ${ }^{-1}$ ),

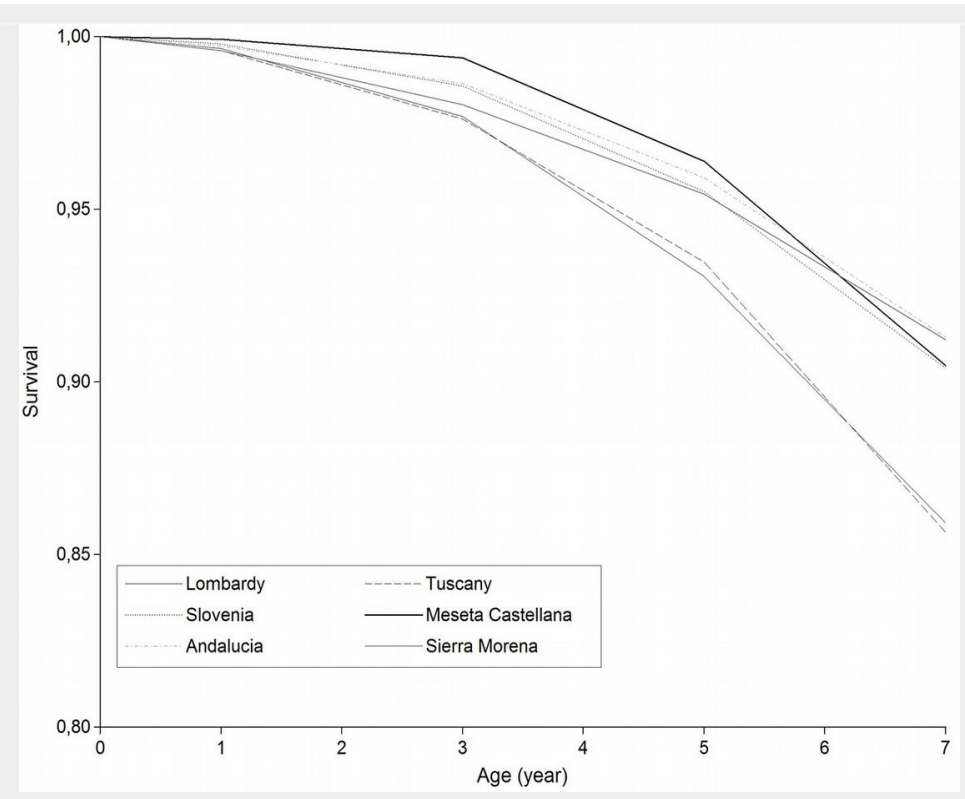

Fig. 1 - Survival curves for six European Stone pine provenances in a trial site in Casablanca (Chile). Study period: 19942001.

Tab. 2 - Density effect as covariable and AIC values for models with and without spatial structure for effects of the assessed Stone pine provenances on production variables.

\begin{tabular}{lcccccc}
\hline Parameter & Cone \# & $\begin{array}{c}\text { Cone } \\
\text { weight }\end{array}$ & $\begin{array}{c}\text { Cone } \\
\text { yield }\end{array}$ & $\begin{array}{c}\text { Height } \\
\text { growth }\end{array}$ & $\begin{array}{c}\text { DBH } \\
\text { growth }\end{array}$ & $\begin{array}{c}\text { Crown } \\
\text { diameter } \\
\text { growth }\end{array}$ \\
\hline $\begin{array}{l}\text { Tree\#/plot } \\
\text { (p-value) }\end{array}$ & 0.0017 & $<0.0001$ & 0.4146 & 0.0991 & 0.0092 & 0.007 \\
$\begin{array}{l}\text { Model with spatial } \\
\text { structure (AIC) }\end{array}$ & 1770 & 4006 & 5045 & 1553 & 2475 & 1232 \\
$\begin{array}{l}\text { Model without spatial } \\
\text { structure (AIC) }\end{array}$ & 1768 & 4004 & 5043 & 1551 & 2473 & 1230 \\
\hline
\end{tabular}

Tab. 3 - Average Stone pine tree size and cone production variables by provenance, Different letters in the same column indicate significant differences between provenances $(P<0.05)$.

\begin{tabular}{|c|c|c|c|c|c|c|}
\hline Provenance & Cone \# & $\begin{array}{l}\text { Cone } \\
\text { weight } \\
\text { (g) }\end{array}$ & $\begin{array}{c}\text { Yield } \\
\left(\mathrm{Kg} \mathrm{ha}^{-1}\right)\end{array}$ & $\begin{array}{l}\text { Height } \\
\text { (m) }\end{array}$ & $\begin{array}{l}\text { DBH } \\
(\mathrm{cm})\end{array}$ & $\begin{array}{l}\text { Crown } \\
\text { diameter } \\
(\mathrm{m})\end{array}$ \\
\hline Lombardy & $7.7^{\mathrm{b}}$ & $236.8^{c}$ & $1116^{\mathrm{b}}$ & $5.1^{\mathrm{b}}$ & $13.9^{\mathrm{d}}$ & $3.0^{d}$ \\
\hline Tuscany & $8.0^{b}$ & $256.3^{b}$ & $1751^{\mathrm{a}}$ & $5.3^{b}$ & $15.3^{c}$ & $3.0^{d}$ \\
\hline Slovenia & $6.3^{c}$ & $294.7^{\mathrm{a}}$ & $1062^{b}$ & $6.1^{\mathrm{a}}$ & $16.1^{b c}$ & $3.3^{\mathrm{bc}}$ \\
\hline Meseta Castellana & $11.4^{\mathrm{a}}$ & $302.3^{\mathrm{a}}$ & $1860^{a}$ & $5.9^{\mathrm{a}}$ & $17.3^{\mathrm{a}}$ & $3.6^{\mathrm{a}}$ \\
\hline Western Andalucia & $5.9^{c}$ & $299.6^{a}$ & $989^{\mathrm{b}}$ & $5.9^{\mathrm{a}}$ & $16.7^{\mathrm{ab}}$ & $3.3^{c}$ \\
\hline Sierra Morena & $7.6^{b}$ & $301.3^{a}$ & $1676^{a}$ & $5.9^{a}$ & $17.0^{\mathrm{ab}}$ & $3.4^{\mathrm{b}}$ \\
\hline Weighted average & 8.3 & 284.3 & 1494 & 5.7 & 16.2 & 3.3 \\
\hline
\end{tabular}

Tab. 4 - Matrix of correlation coefficients ( $p$-values in parenthesis) for growth and cone production variables in the studied Stone pine provenances.

\begin{tabular}{|c|c|c|c|c|c|c|}
\hline - & $\begin{array}{l}\text { Height } \\
\text { growth }\end{array}$ & $\begin{array}{l}\text { DBH } \\
\text { growth }\end{array}$ & $\begin{array}{l}\text { Crown } \\
\text { growth }\end{array}$ & $\begin{array}{l}\text { Cone } \\
\text { weight }\end{array}$ & Cone \# & $\begin{array}{l}\text { Cone } \\
\text { yield }\end{array}$ \\
\hline $\begin{array}{l}\text { Height } \\
\text { growth }\end{array}$ & 1 & - & - & - & - & - \\
\hline $\begin{array}{l}\text { DBH } \\
\text { growth }\end{array}$ & $\begin{array}{c}0.98 \\
(<0.0001)\end{array}$ & 1 & - & - & - & - \\
\hline $\begin{array}{l}\text { Crown } \\
\text { growth }\end{array}$ & $\begin{array}{c}0.98 \\
(<0.0001)\end{array}$ & $\begin{array}{c}0.99 \\
(<0.0001)\end{array}$ & 1 & - & - & - \\
\hline $\begin{array}{l}\text { Cone } \\
\text { weight }\end{array}$ & $\begin{array}{c}0.66 \\
(0.0028)\end{array}$ & $\begin{array}{c}0.71 \\
(0.001)\end{array}$ & $\begin{array}{c}0.74 \\
(0.0005)\end{array}$ & 1 & - & - \\
\hline Cone \# & $\begin{array}{c}0.73 \\
(0.0006)\end{array}$ & $\begin{array}{c}0.73 \\
(0.0006)\end{array}$ & $\begin{array}{c}0.79 \\
(0.0001)\end{array}$ & $\begin{array}{c}0.84 \\
(<0.0001)\end{array}$ & 1 & - \\
\hline $\begin{array}{l}\text { Cone } \\
\text { yield }\end{array}$ & $\begin{array}{c}0.67 \\
(0.0024)\end{array}$ & $\begin{array}{c}0.64 \\
(0.0042)\end{array}$ & $\begin{array}{c}0.71 \\
(0.0011)\end{array}$ & $\begin{array}{c}0.76 \\
(0.0003)\end{array}$ & $\begin{array}{c}0.95 \\
(<0.0001)\end{array}$ & 1 \\
\hline
\end{tabular}




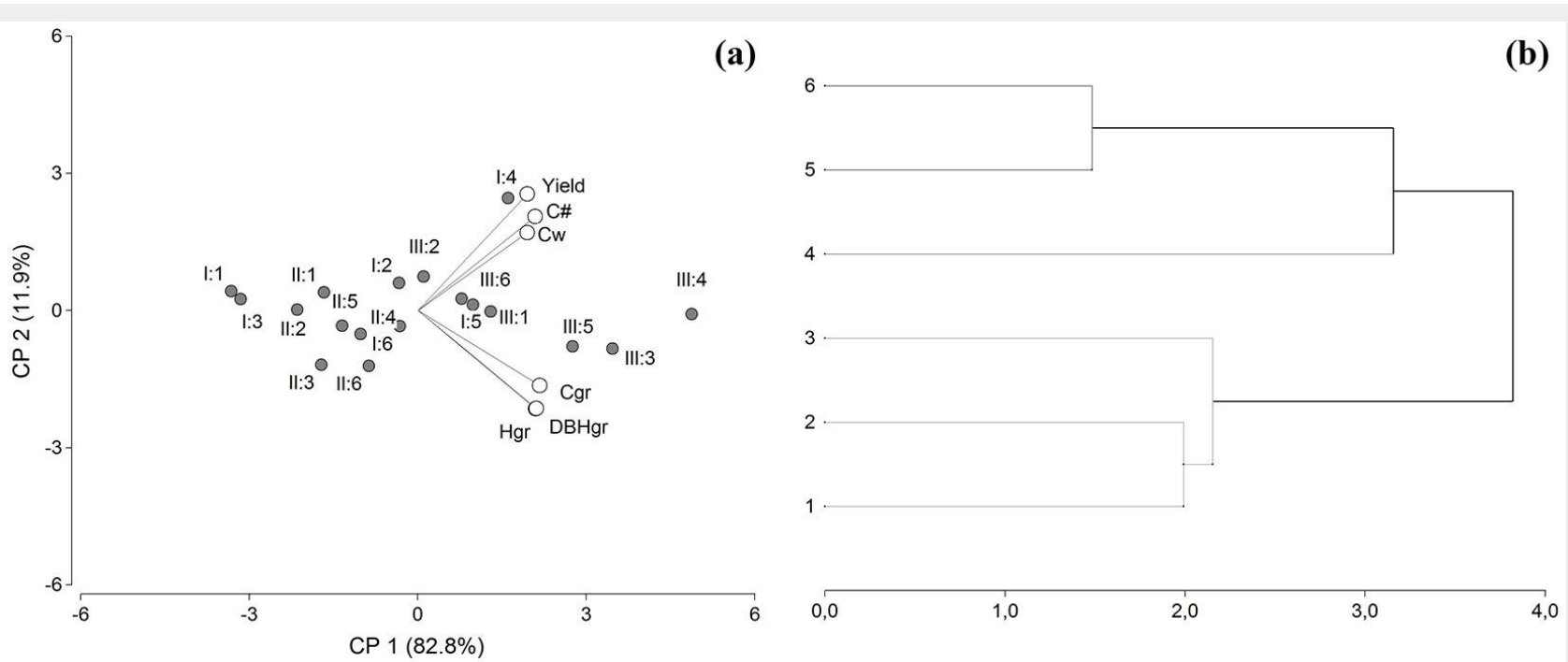

Fig. 2 - Results of the multivariate analysis: (a) Biplot for stone pine growth and productive variables according to provenance and block. (b) Provenance Cluster analysis. (1): Lombardy; (2): Tuscany; (3): Slovenia; (4): Meseta castellana; (5): Western Andalucia; (6): Sierra Morena. Blocks are coded as I, II and III. (C\#): cone number; (Cw): cone weight; (Hgr): height growth; (DBHgr): DBH growth; (Cgr): crown diameter growth; (Yield): cone yield. whereas the lowest values of cone weight
$(237 \mathrm{~g})$, height $(5.1 \mathrm{~m})$ and DBH $(13.9 \mathrm{~cm})$ was recorded for the Lombardy provenance. Western Andalucia showed the lowest cone number (5.9) and yield (989 kg $h \mathrm{a}^{-1}$ ). Despite its low vegetative development, Tuscany provenance showed interesting values of cone production and yield ( 8 and 1751, respectively). The three Spanish provenances had a cone weight close to $300 \mathrm{~g}$, which was significantly higher than that of the Italian provenances.

Tab. 4 presents the coefficient correlation matrix, showing high and statistically significant correlations among all the studied variables.

Results of the multivariate analysis are displayed in Fig. 2. The biplot of the two principal components (Fig. 2a), explaining together $94.7 \%$ of the total variation, clearly shows that block III was positively correlated to growth and productive parameters. We found a statistically significant $(p<0.01)$ positive correlation between individual cone production and weight, and among all vegetative growth indicators.

The classification analysis carried out on provenances based on growth and production parameters clearly revealed three clusters (Fig. 2b), the first grouping the Italian and Slovenian provenances $(1,2,3)$, a second group including the two Spanish provenances Andalucia and Sierra Morena $(5,6)$, and the last group that included only the provenance Meseta Castellana (4), also from Spain.

\section{Discussion and conclusions}

Most of the tree species used in forest plantations are selected for their high survival rates (Vilà et al. 2005), as survival is considered a key variable for the establishment success at early stages and for the adaption of provenances to the environment. In this study, survival of stone pine trees was high for all provenances during the first seven years, confirming the species adaptability to harsh soil and climatic conditions, as stated by Mutke et al. (2008) and Sánchez-Gómez et al. (2009). The Log Rank Test applied to the estimated survival curves showed significant statistical differences among provenances, with the Italian provenances exhibiting the lowest survival over time (Fig. 1). These results may be attributed to differences in climatic and soil conditions between the study area and those in central and northern Italy, where the climate is more humid. Accordingly, Carrasquihno \& Gonçalves (2013) reported genetic variability in provenance survival at different ages, with values ranging between 90.1 and $95.1 \%$ at age 6 , and $50.8 \%$ at age 4 in three studied sites, and values at age 6 similar to those recorded for the four provenances with the best performance in this study.

Growth and productive variables were significantly affected by block effects, as previously suggested by Loewe et al. (2012). This result may be attributed to a microsite effect, likely due to the higher soil volume available for roots in block III, and confirms the species sensitivity to environmental conditions (Court-Picon et al. 2004, Mutke \& Chambel 2008, Mutke et al. 2012, Mutke et al. 2013).

In this study, the tree height reached at 19 years after planting showed statistically significant differences among provenances, as previously reported in several studies (Gordo et al. 2007, Mutke et al. 2010, Carrasquihno \& Gonçalves 2013). The best performance of Spanish provenances in terms of DBH and crown diameter could be explained by the more arid conditions in their area of origin compared with those of the other provenances, allowing a better adaptation of the Spanish provenances to the conditions of the trial site in Casablan- ca. This assumption highlights the important adaptation potential of the species in Chile, as already stated by Gordo et al. (2009) and Mutke et al. (2008). These results are in agreement with those reported by Voltas et al. (2008), who suggested that less favorable growing conditions could enhance intraspecific differences between seed sources.

The selection of genotypes by provenance can contribute to the planning of enhanced pine nut productive plantations, as provenance effect was found to be significant for cone weight and individual cone production in this study. However, these results are contrasting with previous reports indicating a low genetic differentiation among Stone pine populations (Fallour et al. 1997, Fady et al. 2008, Vendramin et al. 2008). On the other hand, Alvarez et al. (2004) observed a high degree of variation in 20 populations of Andalucia Stone pine using megagametophyte storage proteins as markers; the values found were even higher than those reported for maritime pine ( $P$. pinaster Ait.) in the Iberian peninsula, which suggests that this particular technique could be useful for analyzing the genetic diversity of this species.

In this study, the provenance from Meseta Castellana had highest initial germination rate in nursery (Tab. 1) and the highest productivity in central Chile (11 cones per tree). Accordingly, Meseta Castellana exhibited a high correlation among growth variables, as well as among productive traits; trees with more cones also had bigger cones, and consequently, higher cone yield (1860 kg ha-1), followed by the Tuscany provenance (1751 kg ha-1), though with a lower vegetative development. Average cone weight in the Casablanca trial (284 g) was higher than that reported by Schröder et al. (2014) in Tunisia (252 g per cone) and similar to values reported by Gonçalves \& 
Pommerening (2012) in Portugal (256 to 280 g per cone).

Correlations between traits were all significant $(p<0.01)$ in this study. In particular, we found a strong correlation between crown diameter growth and cone weight ( $r$ $=0.74, p=0.0005)$, whereas Gonçalves \& Pommerening (2012) reported a lower value of correlation for the same traits $(r=$ $0.46 ; p \leq 0.005$ ).

The cluster analysis based on growth and production traits identified three provenance groups, showing that Meseta Castellana was similar to the other two Spanish provenances (Western Andalucía and Sierra Morena), with provenances from Italy and Slovenia performing similarly. The fact that seed sources from low latitudes had the best performance under dry conditions was expected, since the native range of stone pine exhibits a clinal increase of aridity towards the south, indicating that southern seed sources would perform better in drier and warmer sites, as already observed in other species (Taïbi et al. 2014).

The results of the principal component analysis (Fig. 2) suggest that plantations with higher growth and productivity were located in block III, whose soil has the highest total depth as well as the highest depth occupied by roots (2.3 times higher than in block II and 3.5 times than in block I).

The maximum observed annual DBH growth (Slovenia: $1.0 \mathrm{~cm}$; Meseta Castellana: $1.2 \mathrm{~cm}$; Western Andalucia: $1.1 \mathrm{~cm}$; Sierra Morena: $1.0 \mathrm{~cm}$; Lombardy: $0.9 \mathrm{~cm}$; Tuscany: $0.9 \mathrm{~cm}$ ), were similar or even higher than that obtained in stone pine plantations in Morocco ( $1 \mathrm{~cm}^{\text {year }}{ }^{-1}-\mathrm{FAO}$ 2007), Spain (0.9 $\mathrm{cm}$ year $^{-1}$ at age 40 in good fertile sites - Sánchez cited by Montero \& Candela 1998) and Tunisia (0.8 cm year $^{-1}$ on coastal dunes - Boutheina et al. 2013 - Tab. 3). However, this growth was lower than the rate reported in Argentina at age $14\left(1.1-2.0 \mathrm{~cm}^{-1}\right.$ year $\left.^{-1}\right)$ by Calderón et al. (2008), probably because the growing conditions were improved by irrigation.

Annual cone production in Spain ranges between 200-600 kg ha-1 (Mutke et al. 2011), whereas in Italy it ranges between $500-1500 \mathrm{~kg} \mathrm{ha}^{-1}$ (Crawford 1995) up to 5000-6000 kg ha-1 (Peruzzi et al. 1998).

Even though stone pine plantations in similar areas could be primarily oriented to soil and environmental protection due to the reduced rainfall, the cone yield values obtained in this work suggest that it is possible to achieve interesting cone production levels in central Chile, despite the local limiting conditions. However, cone production may largely vary among years according to weather conditions (Mutke et al. 2005). Indeed, our results are based on one-year data set and therefore should be considered as an indication of the provenance production, and may not well represent long-term trends.

Stone pine plantations in central Chile can be planned to enhance the species devel- opment and production by selecting appropriate genetic material. Selection should be based on the match of the material to site characteristics and the use of correct management practices, increasing the site plantation potential. Our results provide useful information to this purpose, and highlight the need to include diversified germplasm in breeding programs, as well as to establish long-term multi-site research trials to select the best genetic material for different sites.

In summary, survival of stone pine trees seven years after plantation was high for all foreign provenances at the study site, with the Italian provenances showing the lowest survival over time, suggesting a poorer adaptation. Meseta Castellana (Spain) was the provenance with the highest growth, production and survival. Therefore, we recommend new plantations in the studied area or its surroundings to be established using seedlings from the provenances that showed the best productive performances. Our results highlight the importance of selecting genetic material whose site of origin shares similar characteristics with that of the plantation site, especially when environmental conditions are challenging for the species. The response in terms of growth and cone production of stone pine provenances selected from a broad geographic area of the species' European distribution reflects their differential adaptation to the tested environment.

\section{Acknowledgements}

VL designed and established the experimental unit and was in charge of its periodic measurement and maintenance during 19 years, and coordinated different projects related to the species and in particular to this experimental unit. VL also wrote most of the manuscript. MB supervised the statistical analysis. $C D$ was in charge of the experimental unit periodic measurement and maintenance between ages 15 and 19 after planting, and contributed to the paper elaboration. AA performed statistical analyses, elaborated figures and collaborated in information gathering and practical issues of the publication. RNC collaborated in data discussion.

The trial was established as part of the project "Silviculture of non-traditional species, a higher productive diversity" funded by INFOR-CORFO (1992-1994); and further supported with the following R\&D projects: "Silviculture of non-traditional species, a higher productive diversity", phase II, funded by the Foundation for Agriculture Innovation (FIA) (1998-2003); "The edible Pine nut of Stone Pine, an attractive business for Chile" funded by INNOVA, CORFO (2008-2012); and "Technique development for producing Stone pine (Pinus pinea) pine nuts, an attractive commercial option for Chile, funded by FONDEF, CONICYT (2012-2016 - Code D1111134). The authors thank Universidad Iberoamericana de
Ciencias y Tecnologías (UNICIT) for providing the terrain and looking after the plantation. We also acknowledge the support from University of Córdoba - Campus de Excelencia CEIA3 (Spain).

\section{References}

Allal F, Sanou H, Millet L, Vaillant A, Camus-Kulandaivelu L, Logossa ZA, Lefevre F (2011). Past climate changes explains the phylogeography of Vitellaria paradoxa over Africa. Heredity 107: 174-186. - doi: 10.1038/hdy.2011.5

Alvarez JB, Toledo MJ, Abellanas B, Martín LM (2004). Use of megagametophyte storage proteins as markers of the genetic diversity in Stone pine (Pinus pinea L.) in Andalucia, Spain. Genetic Resources and Crop Evolution 51: 621627. - doi: 10.1023/B:GRES.0000024647.74194. $4 \mathrm{e}$

Ávila A, Delard C, Loewe MV (2012). Zonas potenciales para pino piñonero en Chile [Potential zones for Stone pine in Chile]. In: “Un nuevo cultivo para Chile, el Pino Piñonero (Pinus pinea L.)" (Loewe MV, Delard RC eds). INFOR-CORFO, Santiago, Chile, pp. 241-246. [in Spanish]

Badal E (2001). La recolección de piñas durante la prehistoria en la Cueva de Nerja (Málaga) [Cone harvest during prehistory in Nerja cave (Málaga, Spain)]. In: “De Neandertales a CroMañones, el inicio del poblamiento humano en las Tierras Valencianas" (Villaverde V ed). Universitat de Valencia, Spain, pp. 101-104. [in Spanish]

Boutheina A, Hedi El Aouni M, Balandier P (2013). Influence of stand and tree attributes and silviculture on cone and seed productions in forests of Pinus pinea L., in northern Tunisia. Options Mediterranéennes 105: 9-14.

Calama R (2004). Modelo interregional de selvicoltura para Pinus pinea L. Aproximación mediante funciones con componentes aleatorios. [Interregional silvicultural model for Pinus pinea L. Approximation by functions with random components]. Doctoral Thesis, Universidad Politécnica of Madrid, Madrid, Spain, pp. 300. [in Spanish]

Calderón A, Bustamante J, Riu N, Pérez S (2008). Comportamiento de coníferas bajo riego en Dique Yaucha, Mendoza, Argentina. [Behavior of conifers under irrigation in Yaucha dam, Mendoza, Argentina]. Revista Facultad de Ciencias Agrarias Universidad Nacional de Cuyo 40 (1): 67-72. [in Spanish]

Carrasquihno I, Gonçalves E (2013). Genetic variability among Pinus pinea L. provenances for survival and growth traits in Portugal. Tree Genetics and Genomes 9: 855-866. - doi: 10.1007/s11295-013-0603-2

Court-Picon M, Gadbin-Henry C, Guibal F, Roux M (2004). Dendrometry and morphometry of Pinus pinea L. in lower Provence (France): adaptability and variability of provenances. Forest Ecology and Management 194: 319-333. - doi: 10.1016/j.foreco.2004.02.024

Crawford M (1995). Nut pines. Yearbook, West Australian Nut and Tree Crops Association 19: 56-66.

Evaristo I, Costa SR, Baeta J, Pais MS (2002). Caracterização molecular de proveniências de $\mathrm{Pi}$ nus pinea L. por RAPD (Random Amplified Polymorphic DNA) [Molecular characterization of 
Pinus pinea provenances by RAPD (Random Amplified Polymorphic DNA)]. Silva Lusitana 10 (1): 53-61. [in Portuguese]

Evaristo I, Tenreiro R, Costa R (2008). Caracterização de parâmetros biométricos e de ácidos gordos em pinhões de populações portuguesas de Pinus pinea L. [Characterization of biometric variables and fatty acids in pine nuts from Portuguese Pinus pinea L. populations]. Silva Lusitana 16 (1): 1-19. [in Portuguese]

Fady B, Fineschi S, Vendramin G (2008). Pino piñonero. Pinus pinea [Stone pine. Pinus pinea]. EUFORGEN, Guía técnica para la conservación genética y utilización del pino piñonero (Pinus pinea). Foresta 40: 2. [in Spanish]

Fallour D, Fady B, Lefevre F (1997). Study of isozyme variation in Pinus pinea L.: evidence for low polymorphism. Silvae Genetica 46: 201-207. FAO (2007). Amélioration du Pinus pinea au Maroc. [Breeding of Pinus pinea in Morocco]. In: Proceedings of the "IUFRO WP Expert Consultation”. Arezzo and Rome (Italy) 21-23 Jun 2007. Fao, Rome, Italy, pp. 5. [in French with English Summary] [online] URL: http://foris.fao. org/static/data/silvamed/

Gandullo M, Sánchez-Palomares O (1994). Estaciones ecológicas de los pinares españoles. [Ecological sites of Spanish pine forests]. Dirección General para la Conservación de la Naturaleza. Madrid, Spain, pp. 184. [in Spanish]

Gómez A, Aguiriano E, Alía R, Bueno MA (2002). Análisis de los recursos genéticos de Pinus pinea L. en España mediante microsatélites del cloroplasto. [Analysis of the genetic resources of Pinus pinea L. in Spain by chloroplast microsatellites]. Investigación Agraria: Sistemas y recursos Forestales 11 (1): 145-154. [in Spanish] González S (2011). Population genetics of Pinus pinea, a species with low genetic variation. In: Proceedings of the "Agropine 2011 International Meeting on Mediterranean Stone pine for Agroforestry". Valladolid (Spain) 17-19 Nov 2011, pp. 17. [online] URL: http://networks.iam z.ciheam.org/agropine2011/

Gonçalves AC, Pommerening A (2012). Spatial dynamics of cone production in Mediterranean climates: a case study of Pinus pinea L. in Portugal. Forest Ecology and Management 266: 8393. - doi: 10.1016/j.foreco.2011.11.007

Gordo J, Mutke S, Gil L (2007). Ausencia de diferenciación ecotípica entre rodales selectos de pino piñonero en la cuenca del Duero. [Lack of ecotype differentiation between selected stone pine stands in the Duero basin]. Investigación Agraria: Sistemas y recursos Forestales 16 (3): 253-261. [in Spanish] - doi: 10.5424/srf/2007 163-01014

Gordo AJ, Calama SR, Rojo GL, Madrigal CG, Mutke RS, Montero GG, Finat GL (2009). Experiencias de clareos en masas de Pinus pinea $\mathrm{L}$. en la meseta Norte [Thinning experiences Pinus pinea $\mathrm{L}$. forests in the North plateau]. In: Proceedings of the " $V$ Spanish Forest Congress - SECF”. Avila (Spain) 21-25 Sep 2009. Junta de Castilla y León, Spain, pp. 13. [in Spanish]

Hijmans R, Cameron S, Parra J, Jones P, Jarvis A (2005). Very high resolution interpolated climate surfaces for global land areas. International Journal of Climatology 25: 1965-1978. doi: 10.1002/joc.1276

Khaldi A, Khouja M, Akrimi N (2009). Results of comparative trials between Stone pine (Pinus pinea L.) provenances in northern Tunisia. Revue Forestière Française 61 (2): 107-116.

Littell RC, Milliken AG, Stroup WW, Wolfinger RD, Schabenberger O (2006). SAS for Mixed Models (2nd edn). SAS Institute Inc., Cary, NC, USA, pp. 814 .

Loewe MV, González M (2003). Sicomoro, grevillea, roble rojo americano, pino piñonero, castaño, ruil y cerezo americano, nuevas alternativas para producir madera de alto valor [Sycamore, silk oak, red American oak, stone pine, chestnut, ruil and black cherry, new alternatives to produce high value timber]. INFOR-FIA, Santiago, Chile, pp. 320. [in Spanish]

Loewe MV, González OM (2007). Pino piñonero: el potencial de su madera y fruto. [Stone pine: potential of its timber and fruit]. Chile Forestal 334: 49-53. [in Spanish]

Loewe MV, Delard RC, González GM, Mutke S, Fuentes DV (2012). Introducción del pino piñonero, Pinus pinea L., en Chile [Introduction of Stone pine, Pinus pinea L., into Chile]. Ciencia e Investigación Forestal 18 (2) 39-52. [in Spanish] Loewe MV, Delard RC (2012). Un nuevo cultivo para Chile, el pino piñonero (Pinus pinea L.) [A new crop for Chile, the Stone pine (Pinus pinea L.)]. Instituto Forestal. Santiago, Chile. pp. 364. [in Spanish]

Montero G, Candela J (1998). Manual de claras para repoblaciones de Pinus pinea L. [Handbook on Pinus pinea L. plantation thinning]. Ed. EGMASA y Junta de Andalucía, Spain. pp. 47. [in Spanish]

Mutke S, Gordo J, Gil L (2005). Variability of Mediterranean Stone pine cone production: yield loss as response to climate change. Agricultural and Forest Meteorology 132:263-272. - doi: 10.1016/j.agrformet.2005.08.002

Mutke S, Iglesias S, Gil L (2007). Selección de clones de pino piñonero sobresalientes en la producción de piña. [Stone pine superior cone production clone selection]. Investigación Agraria: Sistemas y recursos Forestales 16 (1): 3951. [in Spanish] - doi: 10.5424/srf/2007161-00996 Mutke S, Chambel M (2008). Strong plasticity in a genetically depauperated tree - the fox or the hedgehog strategy? Stone pine provenances performance in Inner Spain. CIFOR, INIA, Madrid, Spain. pp. 17.

Mutke S, González-Martínez S, Viana A, Gordo J, Gil L (2008). El pino piñonero, un pino atípico. [Stone pine, an atipic tree]. Cuadernos de la Sociedad Española de Ciencias Forestales 24: 81-85. [in Spanish]

Mutke S, Gordo J, Chambel M, Prada M, Alvarez D, Iglesias S, Gil L (2010). Phenotypic plasticity is stronger than adaptive differentiation among Mediterranean stone pine provenances. Forest Systems 19 (3): 354-366. - doi: 10.5424/fs/2010 193-9097

Mutke S, Pastor A, Picardo A (2011). Toward a traceability of European pine nuts "from forest to fork". Options Méditerranéennes 105: 105109. [online] URL: http://networks.iamz.ciheam .org/agropine2011/files/OM-A105-PDF.pdf

Mutke S, Calama R, González-Martínez S, Montero G, Gordo J, Bono D, Gil L (2012). Mediterranean Stone pine: botany and horticulture. Horticultural Reviews 39: 153-201.

Mutke S, Gordo J, Khouja ML, Fady B (2013). Low genetic and high environmental diversity at adaptive traits in Pinus pinea from provenance tests in France and Spain. Options Méditerranéennes 105: 73-79. [online] URL: http:// networks.iamz.ciheam.org/agropine2011/

Nasri N, Khaldi A, Fady B, Triki S (2005). Fatty acids from seeds of Pinus pinea L.: composition and population profiling. Phytochemistry 66: 1729-1735. - doi: 10.1016/j.phytochem.2005.05. 023

Peruzzi A, Cherubini P, Gorreri L, Cavalli S (1998). Le pinete e la produzione dei pinoli dal passato ai giorni nostri, nel territorio del parco di Migliarino, S. Rossore, Massaciuccoli [Pine forests and pine nut production in the Migliarino S. Rossore Massaciuccoli Park, from the past to nowadays]. Ente Parco Regionale Migliarino San Rossore Massaciuccoli, Pisa, Italy, pp. 134. [in Italian]

Prada MA, Gordo J, De Miguel J, Mutke S, Catalán G, Iglesias S, Gil L (1997). Las regiones de procedencia de Pinus pinea L. en España [Provenance regions of Pinus pinea L. in Spain]. Org. Autónomo de Parques Naturales, Madrid, Spain, pp. 111. [in Spanish]

Raimondo FM (2013). Biodiversità nella dendroflora italiana [Biodiversity of Italian dendro flora]. L'Italia Forestale e Montana 68 (5): 233257. [in Italian] - doi: 10.4129/ifm.2013.5.01

Sánchez-Gómez D, Cano F, Cervera M, Aranda I (2009). Variabilidad fenotípica en respuesta al estrés hídrico en una especie forestal genéticamente homogénea: Pinus pinea L. [Phenotipic variability in response to water stress in a genetically homogeneous forest species: Pinus pinea L.]. In: Proceedings of the "V Spanish Forest Congress - SECF ". Avila (Spain) 21-25 Sep 2009. Junta de Castilla y León, Spain, pp. 2-7. [in Spanish]

SAS Institute (2006). SAS ${ }^{\circledR}$ data integration studio 3.3: user's guide. SAS Institute Inc., Cary, NC, USA, pp. 243.

Schröder K, Khaldi A, Hasnaoui A (2014). Analyse de la chaîne de valeur "Pignons de pin" en Tunisie [Pine nut value chain analysis in Tunisia]. S.I.-GIZ, France, pp. 48. [in French]

Taïbi K, Del Campo A, Mulet J, Flors J, Aguado A (2014). Testing Aleppo pine seed sources response to climate change by using trial sites reflecting future conditions. New Forests 45 (5): 603-624. - doi: 10.1007/s11056-014-9423-y

Vendramin G, Fady B, González-Martínez C, Sheng Hu F, Scotti I, Sebastiani F, Soto A, Petit JR (2008). Genetically depauperated but widespread: the case of an emblematic Mediterranean pine. Evolution 62 (3): 680-688. - doi: 10.1111/j.1558-5646.2007.00294.x

Vilà M, Inchausti P, Vayreda J, Barrantes O, Gracia C, Ibañez JJ, Mata T (2005). Confounding factors in the observational productivity-diversity relationship in forests. Ecological Studies 176: 65-86. - doi: 10.1007/3-540-26599-6_4

Voltas J, Chambel M, Prada M, Ferrio J (2008). Climate-related variability in carbon and oxygen stable isotopes among populations of Aleppo pine grown in common-garden tests. Trees 22: 759-769. - doi: 10.1007/s00468-008-0236-5

West B, Welch K, Galecki A (2014). Linear mixed models: a practical guide using statistical software. CRC Press, New York, USA, pp. 440. 